\title{
Experiential Study in Learning English Writing: An Inquiry into Saudi Learners' Concerns
}

\author{
Sahal R. Al Shammari ${ }^{1}$ \\ ${ }^{1}$ Department of English Language Skills, Preparatory Year \& Supportive Studies, Rafha Male Campus, Northern \\ Border University, Kingdom of Saudi Arabia \\ Correspondence: Department of English Language Skills, Preparatory Year \& Supportive Studies, Rafha Male \\ Campus, Northern Border University, Kingdom of Saudi Arabia. E-mail: alshammarisahal@gmail.com
}

\author{
Received: February 27, 2018 Accepted: March 29, 2018 Online Published: April 3, 2018 \\ doi:10.5539/ijel.v8n4p181 URL: https://doi.org/10.5539/ijel.v8n4p181
}

\begin{abstract}
Writing plays a prominent role in learning a second language or foreign language. Research mainly focused on the development of writing skill from the teachers or trainers' perspectives, but in the recent studies researchers have explored students' concerns about writing skill and the difficulties they encounter in the process. The learners are fully aware of the challenges and their expectations of the courses. The purpose of this study is to investigate students' perceptions about academic writing courses or writing in general and to investigate the differences they observe about the teaching practice followed in the kingdom as well as ELP in the USA. A total of 03 students (from three different provinces of the KSA) from the pre-university English language program (Applied English Center, Kansas University, USA) for Saudi students enrolled for various courses in their masters program in the US universities participated in this study. The general design of the study was qualitative in nature as a questionnaire and a focus-group interview were implemented for data collection. The overall results demonstrated that the difference in teaching strategies is a significant factor which poses a question mark on the professional training expected of the teachers involved in various universities in the kingdom. The major findings demonstrated students' awareness of their needs and ESL writing requirements and how teaching writing in MT or so to say L1 influences their ESL learning. The study concluded with recommendations for future research.
\end{abstract}

Keywords: skill, writing skill, view, academic writing, text, Saudi ESL learners

\section{Introduction}

No doubt that English writing is difficult and not easy to master whether it is in the L1 or the L2 (Nunan, 2000), because it is not concrete and entitled a creative activity (Aljamhoor, 1996). Many studies indicate that weakness in writing skills is a dominant feature of Arab L2 learners (Ahmed, 2010; Doushaq, 1986; Hashim, 1996; Rababah, 2002) and Saudi L2 learners in particular (Alrabai, 2014, 2016; Alshammari, 2016; Elyas \& Picard, 2010; Grami, 2010; Mohammad \& Hazarika, 2016). However, a few studies have explored the reasons behind this weakness and investigated the teachers' perception of the same.

The skill of writing in English presents a difficulty for Arab students in general (Rababah, 2002) and Saudi students in particular (Ali Al-Khairy, 2013). The researcher gave free courses to Saudi students at the Applied English Center at Kansas University to prepare them for TOFEL and IELTS standardized tests. Most of the students who attended these courses struggled with writing. Moreover, all the students who had taken these tests revealed that their lowest scores were in writing skill. This is because writing is not an easy skill to learn or to teach. Writing is only taught in school in compulsory education, unlike the skills of speaking and listening. Writing combines thought processes, feelings, and social interactions (Perin, 2013). Therefore, there is a need to explore the difficulties encountered by Saudi learners while learning to write in English. There are, however, three important variables that should be considered while analyzing the situation and circumstances that surround such a process. First, the influence of the L1 and how far it will interfere with the L2; second, the context of learning English as a second language and how this is different from learning in the context of a foreign language; finally, English writing style, as well as the writing instruction for English native speakers. Through this framework we can conceptualize how the data will be organized and analyzed: 


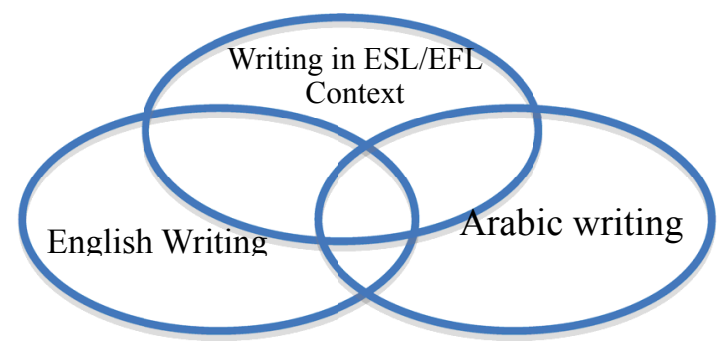

\section{Writing as a Skill: A Review}

In general, writing skills are difficult to master because they combine thought, feeling, and social interactions (Perin, 2013) and demands cognitive analysis and linguistics synthesis (Seitova, 2016). However, the skill of writing in English, particularly the argumentative type, presents as an obstruction for Arab L2 learners in general (Ahmed 2010; Doushaq 1986), and Saudi students in particular (Ali Al-Khairy, 2013; Alrabai, 2014, 2016; Elyas \& Picard, 2010; Grami, 2010; Mohammad \& Hazarika, 2016). One reason to such weakness is due to the different cultural background between L1 and L2. Ferris (1994) examined 60 argumentative papers for undergraduate student; half of them are native speakers and the other half are non-native speakers. The results of the study revealed clear differences between the two groups regarding the length of writing, and the use of counter-arguments (Ferris, 1994). Ferris (1994) indicated that her ESL students in writing is the result of poor composing ability rather than inadequate proficiency in language in general (Ferris, 1994). Another explanation is related to the difference between native and non-native argumentative writing and rhetorical traditions such Confucian, Taoist, and Buddhist whereas English language which is based on Aristotelian notions of directness, justification, and proof is somewhere different in nature (Hinkel, 1997).

In the same regard, Chinese writers demonstrate epistemological and dialogical emphases and highlight the need of analogies whereas American writers do have different approach altogether (Liu, 2005). Though that the Western influence considered powerful and in the past century and explain the similarities between the Chinese and English rhetorical conventions, the Marxist philosophy is still the dominant philosophy in China which is quite different from English culture (Liu, 2005). The influence of cultures on writing has a strong impact on the Persian argumentative writing wherein the Iranian writers use various indirectness modes of expression since they prefer to avoid refutation and direct arguments (Biria1 \& Yakhabi, 2013).

The argumentative writing between Arabic and English does not go far from this dissimilarity where the former tends to use the Thorough-Argumentation and the latter prefer the Counter-Argumentation style (Hatim, 1997). In the Thorough-Argumentation style the writer usually imply to the opponent's claim and avoid the direct addressing to his argument. Hatim (1997) addresses the Arabic argumentative writing as thesis -substantiation conclusion while the English prefer to address the opponents directly i.e., thesis - opponents - substantiation conclusion. In Arabic, the use of the Through-argumentation to solidarity, politeness, and face-saving as factors of preference of this style (Hatim, 1990).

This may explain the difficulty for L2 learners when they write in the target language because when write in a L2 context, L2 learners evokes the L1 as a framework for their writing (Connor, 1987; Kaplan, 1966). Adding to this most of writing instructions seen in ESL classroom based on drills and exercises (Parker, Lara-alecio, \& Gomez, 1996). In addition, instructions in teaching writing in Arabic focus mainly on grammar and the feedback is merely correcting sentences with fixed phrases such as "good" and "excellent" (Alshammari, 2011; Liebman, 1992). This can be related to adapt the Product-Approach in teaching writing in the classroom which focuses on the grammatical accuracy of student's writing (Badger \& White, 2000) and emphasizes the rhetorical drills (T Silva, 1990). However, the Product Approach is widely common in teaching Arabic in Saudi Arabia (Bakry \& Alsamadani, 2015) as well as English (Al-hazmi \& Scholfield, 2007; Ezza, 2010; Grami, 2010). The challenge faced by the L2 learners in English argumentative writing lies on the contrast between English and Arabic argumentative style rather the linguistic competence of the students.

\subsection{Teaching Arabic Writing}

Arabic writing is considered difficult even for native Arabs due to several reasons. First, in each Arab country there are at least two different languages; Classical Arabic and Colloquial Arabic (Thompson-Panos \& Thomas-Ruzic, 1983). First, the Classical Arabic is used usually in the written form and is orally limited to the formal news preaching. Therefore, the students when learn to write in the schools they learn a different language from the language they speak in their day to day lives. Second, at high school level, the writing instructions are 
limited to orthography, grammar, and organization (Al-Ali, 1998, as cited in Alnofil, 2003). Unlike English writing, students while learning Arabic writing do not have training on writing strategies such as pre-writing and post-writing (Alnofil, 2003).

\subsection{Teaching English Writing}

Teaching English writing developed over years where the Product Approach was the dominant approach of teaching writing before the 70 s and teaching writing was focusing on prescriptive text features of model prose written by exemplary writers (Nystrand, 2006). However, the Product Approach was gradually abandoned in favor of the Process Approach and concentration of writing shifted from the final product to the process of writing itself and writing was viewed as a cognitive process (Britton, 1975; Moffett, 1968). One of the first attempts in this regard was (Rohman, 1965) who suggested his Stage Model of Writing which consists of three stages: pre-writing, writing, and post-writing. However, Rohman's (1965) model was criticized that it was a linear model (Emig, 1971) and, as a result, new models of writing i.e., Support Recursiveness in Writing emerged at the beginning of the 80s such as (Flower \& Hayes, 1981); (Zimmermann, 2000). Though Flower and Hayes's (1981) were criticized (Faigley, 1986; Zimmermann, 2000), however, it maps the actual mental behaviors of writers at work (Alharthi, 2012). Moreover, Rohamn's (1965) model as well as Flower \& Hayes's (1981) and other models and studies strengthened the process approach. Therefore, the Process Approach considered as the dominant approach in teaching writing in the middle and high school in the United States (Applebee \& Langer, 2009).

While deciding the best instruction method and models for teaching writing to the native English speaker is still controversial, there are different sources for developing the best instruction in teaching writing. Graham and Harris (2013) group these into three main sources: the wisdom of professional writers, teachers who teach writers, and scientific studies. Although the latter has some flaws regarding generalization, it still provides the field of education with continuous research and studies. For instance, Song \& Ferretti (2013) cited many studies, which investigate the interventions that have been implemented to improve students' argumentative writing (De La Paz \& Graham, 1997; Deatline-Buchman \& Jitendra, 2006; Ferretti, Macarthur, \& Dowdy, 2000; Graham \& Harris, 1989; Sexton, Harris, \& Graham, 1998). Finally and more importantly, forty-six states agreed to implement the Common Core State Standard (CCSS) in their educational systems (Graham \& Harris, 2013). The CCSS emphasizes learning writing and considers it, along with writing instruction, a central element in school reform. This increasing interest in writing on theoretical, scientific, and applied levels shows us the huge gap between teaching writing in Arabic and English languages.

\subsection{Writing with reference to ESL and EFL}

There has been a huge debate estimating the influence of L1 on L2 in respect of writing. Some researchers believe that L2 learners should have the same instruction with regard to writing as native speakers have in an English classroom (Zamel, 1976). In other words, ESL and EFL writing instruction should not be different from native speaker writing instruction. On the other hand, some researchers believed that although L2 learners of English, for instance, are learning the same language as native speakers, therefore they should not be treated as native speakers because of the influence of their L1 (Raimes, 1987; Silva, 1988). However, Silva (1994) proposed a solution by recommending more choices for the L2 learners if they want to enroll in separate L2 writing classes or with native speakers sections (Silva, 1994).

Barry (2014) conducted a study on the impact of L1 Arabic on L2 English writing. She concluded that L1 Arabic influences ESL learners' English writing, with specific and predictable errors in the use of punctuation, conjunctions, capitalization, and articles as the most difficult concepts. More interestingly, she revealed that L2 Arab learners tend to write strong descriptive narrative writing which is often influenced by the colorful and poetic narrative tradition of the Arabian Peninsula. However, this type of narrative writing needs a strong knowledge of syntax and lexical meaning and usually the L2 learners struggle in these areas (Barry, 2014). Finally, Hashim (1996) reviewed literature that investigated Arab-speaking learners' the most common errors and concluded that the source of error is the influence of the native language; and that in processing English syntactic structures Arabic speakers adopt certain strategies similar to those of first-language learners including simplification and over-generalization.

Through this brief review of the variables that interfere while Saudi learners learn English writing as a second/foreign language, the study will try to answer the following research questions:

1) What are Saudi students' experiences of learning English writing in Saudi Arabia?

2) What are Saudi students' experiences of learning English writing in the United States? 
The first question concentrates on learning English as a foreign language, while the second one focuses on learning English as a second language.

\section{Methods}

The framework that I chose for this study, along with the research questions, implies that the three necessary characteristics for the participants of the study are: first, they are Saudi students, second, they have studied English in Saudi Arabia, and third, they have studied English in the USA. It was preferable to find participants who spent the same period of time studying English in the USA. However, while all participants spent the same amount of time studying English in Saudi Arabia, i.e., four years; they varied in the time spent studying English in the USA. All participants were Saudi students who learnt English language in an English department at three different universities in Saudi Arabia. As they had a high grade point average (GPA), each one of them were assigned to be a teaching assistant (a faculty member) in the English department and the university offered them scholarships to earn MA and $\mathrm{PhD}$, either in linguistics, translation, or literature. All of them, at the time of conducting the study were studying in the Applied English Center (AEC) at Kansas University.

In this study they were labeled in numbers according to the order of conducting the interview. While conducting the study, the first participant was studying in the AEC for four semesters and he was in the fourth level (AEC has five levels), whereas the second and third participants had just arrived this semester and they were in fifth level and level one respectively. All of them took the International English Language Testing System test (IELTS). Their scores were: 5.5, 6.5, and 6.5 for participants 1, 2, and 3. The minimum score required for language admission in a Master's program is 6.5. Therefore, participants 2 and 3 were officially qualified to enter a Master's program, while participant 1 had still not achieved the required condition. It must be mentioned that having the required score in IELTS does not guarantee the admission to a Master program. In other words, all the three participants are falling under the pressure of getting admission to a Master program. Their scholarships are of a specific duration for each stage (language program, Master, $\mathrm{PhD}$ ). For example, they should finish the English language program and get admission within 24-months period or their scholarship would be cancelled.

After receiving the approval to conduct the study with three participants, I asked them to advise me of their free times in which we could conduct the interviews. All of them preferred to have the interview in the Watson library, because it is near to the Fraser building where most of the AEC classes are held. The interviews were conducted in Arabic instead of English. In fact, I was confronted with two choices: first, to conduct the interview in English and know that the participants will not elaborate because of the language barrier; second, to conduct the interview in Arabic and translate it into English. I chose the second option, although I knew that a translation of the transcript would not always convey the exact meaning. However, I estimated that the learners would reveal more information about their attitude and experiences in their L1 language, and this was more important than using L2 with limitations.

Following Rubin \& Rubin's (2011) advice to focus on a dozen of questions to give the participants enough time to elaborate, I developed seven questions that served the purpose of the study and answered all the research questions (Rubin \& Rubin, 2011). Three questions were about studying English writing as a foreign language in Saudi Arabia and three about studying English writing as a second language at the AEC. Also, as Rubin \& Rubin (2011) stated that vividness comes from asking questions about participants' background, so one question was about the participant's background in writing in Arabic. Specifically, this question was about their experiences in learning Arabic writing. However, this question had follow-up questions that differed from one participant to another. Moreover, this question was added after two participants (participants 1 and 2) had their interviews. Therefore, short separate meetings with participant 1 and 2 were arranged and they answered the question in relation to their experience in their L1 and the follow-up questions related to that question.

I had the permission from all the three participants to record the interview, as it was indicated on the consent form, but I also confirmed if they approved by asking them verbally if they were comfortable with recording of their interview. At the beginning of the interview I explained to all the participants what the interview was about and why they were chosen as participants in this study. I also explained to them the benefits that are expected from this study and how it would contribute to enlighten the academic audience in Saudi Arabia with the problems and struggles that Saudi students experience with their writing skills. More importantly, this study will be the first step toward designing a model to improve foreign language learners and L2 learners' writing, particularly Saudi learners.

For the validity of the study, the researcher eliminated participants who are from the same university in Saudi Arabia. Having different participants from different universities enabled the study to look at the challenges from 
different perspectives and also to see the common strength and weakness at the English program in Saudi Arabia regarding writing. However, it was not possible to apply the same rule on studying English writing in the USA, because it was difficult to find different participants who were studying in English language institutions at different universities.

Another point to support the validity is that the researcher had the same experience of learning English in both programs. He also shares the same language as the participants, which enables him to translate their concepts about writing with a minimum risk of misunderstanding. To avoid the bias, the researcher did not interfere or argue about what the participants stated during the interview and kept his contributions to the minimum level.

However, the study has some limitations that cannot be ignored. First, the small number of participants i.e. three participants, that could prevent generalization of the results of the study unless more empirical studies support the similar claims. However, having three different participants who studied in three different programs and each one of them does not know who were the other two participants might suffice the claims by increasing the credibility of the interview. Also, there was no time to compare the participants' English writing while they were studying English as a second language or the foreign language contexts. In other words, I did not have additional sources to confirm the participants' ability to write in both contexts. However, the study is based on their experience, which is more important than their truthfulness about their abilities. Also, the researcher asked them about their scores in the IELTS and, more specifically, in their writing skills, which adds more credibility to their claims about their abilities in writing.

\section{Results}

The results and the findings of the study will be grouped into three sections. The first section considers the participants' experience in their L1 language. The second section considers their experiences in learning English writing as foreign language in Saudi Arabia. Finally, a section discusses their current experience in learning writing as a second language in the AEC. This is followed by general findings, relating to these three sub-categories and analyzing the main findings.

\subsection{Participants' Experience in Arabic Writing}

All participants agreed that they did not receive any specific instruction regarding writing in Arabic. Also, they revealed that they are not aware of the style of Arabic writing or if there are any different types of writing in the Arabic language. Along with Barry (2014) they agree that the main feature of Arabic writing that it is "poetic narrative" writing. However, they do not know the basis of this feature, or why the strong writings in Arabic tend to have this feature. The literature review revealed that the Quranic style has this feature and, therefore, it influences the Arabic writings in the Arabian Peninsula which includes Saudi Arabia and other gulf countries such as Kuwait, Qatar, UAE, Oman, and Yemen (Koch, 1983).

Two of the participants (participants 2 and 3), revealed that they liked writing in Arabic and they attempted prose writing which they posted online. They felt encouraged with the compliments they received as well. Unlike the two other participants, participant 1, however, admitted that he did not have any interest in writing in Arabic and he did not remember if he had posted prose writing or any other type of writing, except short comments on Facebook and Twitter.

Regarding practice in writing, all participants who studied in three different regions in Saudi Arabia said that they did not have any systematic practice in writing during their school education. The two participants who liked to write in Arabic said that they practiced apart from their formal curriculum. None of them could remember any activities related to writing, like clubs, programs, or competitions which motivated writing during their K-12 study. Also, the same was true even outside school where there was no motivation for writing from family or society. The two participants who stated that they liked writing justified that they acquired the ability to write by reading and exploring words by themselves.

The result of this section was not surprising because it was compatible with the sources of previous research that investigated writing strategies in Arabic (Aljamhoor, 1996; Alnofal, 2003; Muhammad, 2001).

\subsection{Participants' Experience in English Writing as a Foreign Language}

It must be mentioned in the beginning of this section that although the questions investigated the participants' experiences in learning English writing in a foreign context (Saudi Arabia); most of their responses were negative as they focused on the challenges they encountered. However, with regard to learning English writing in the context of a second language, they mentioned both negative and positive aspects in their learning of English which were related more to their experience, rather than only discussing challenges. 
As mentioned before, among the three participants, each one has a bachelor degree in English from three different universities in Saudi Arabia. However, they all agreed that their programs did not have a strong and clear plan that could produce learners with writing ability in general and argumentative writing in particular. For example, participant 3 stated that during his English program, he did not receive any tuition related to types of writing or functions of writing. Generally, the topics given were only guided for specific tasks such as finding errors related to punctuation and capitalization. Furthermore, participant 2 added that faculty members (instructors with $\mathrm{PhD}$ degree) in his department did not concentrate on writing skills or gave more specific instruction about writing; rather they gave these courses to teaching assistants who lacked the experience and the knowledge. As a result students had high scores in the writing course but with very little knowledge of how to write. The researcher asked the three participants the following questions: when did you first hear of the concepts like thesis statement of an essay? All of them said that they heard it for the first time in the AEC.

With regard to the practice of writing inside the classroom, all the participants agreed that they did not have any sort of practice in writing. There were some exceptions, however, such as when the lecturer asked them to write a small paragraph, with instructions to mark the punctuation and capitalizations well. However, when it came to writing a complete essay, they all revealed that they only wrote a complete essay in the test, for which they never received any feedback.

This data gives us a general picture of how the teaching of writing in English departments is progressing in Saudi Universities. Although the teaching of English writing is better than the teaching of Arabic writing in some aspects, as the teaching of English does not reach the level of proficiency that enables students to write an English passage in an academic way. According to the participants' revelations, there could be three reasons for the failure of such English programs in their universities: instructors, strategies, and monitoring. Two participants revealed they were taught either by teaching assistants or lecturers who did not have sufficient knowledge of writing. The third (participant 1) was taught by an assistant professor but his method of teaching was not effective. However, all the participants revealed that their teachers in English writing courses were responsible for their weakness in the skill of writing.

Another potential issue is the strategies that their teachers followed in teaching English writing. First, there were no clear strategies in writing. All participants stated that the faculty members who taught them writing course usually used a textbook for the writing course and spent most of the course trying to finish it. They did not practice writing in the classroom. The best case was participant 1 who said that his teacher made a file for the students and asked them to write an essay each week. However, he did not return the essays which were the basis of student's final evaluation. There was no feedback mechanism so that the learners could see the comments, or to see how their essays were graded. In fact, this incorrect strategy of teaching produced resulted in poor technique that participant 1 and his colleagues adapted. According to participant 1 , they began to memorize some topics from their textbook and used those with some modifications for their assignments. They used this technique because they noticed that their professor's attention was focused on evaluation not on teaching. Also, as they did not receive any feedback or they had any discussions on the assignments they submitted, it did not really matter to them if they memorized or used their own ideas.

Finally, according to all the participants, there was no monitoring or accountability check of any faculty members in all the three universities. They all revealed that during their English writing course at their universities in Saudi Arabia, they did not have a syllabus or knowledge of the goals of the course. Also, at the end of the semester there was no evaluation of the instructors by the learners as it is in the AEC. Therefore, according to them, their weakness in writing and other skills was the result of the failure of accountability. For example, participant 1 said that the instructor only covered a few pages of the course textbook during the whole semester. Most of lectures were conducted about issues that were not within the textbook topics. They also agreed that there was no systematic process of writing instruction that they could follow when they wanted to write an essay.

These reasons behind the weakness in teaching English writing in the three programs imply that teaching English in the context of a foreign language is influenced by the style of the native language. For example, the Arabic language, as cited by the literature (M.N., 2003), tends to have a long narrative poetic style of writing and the instruction was limited to grammar and organization. On the other hand, all of the English programs, according to the three participants, focused on secondary issues such as capitalization and punctuation. The English programs in the foreign context do not have clear instruction about different types of writing, for instance argumentative writing, and they only focus on marginal aspects of writing. This is very similar to the way of teaching Arabic writing in Saudi Arabia. 


\subsection{Participants' Experiences in Learning English Writing as a Second Language}

Unlike the previous section, in this section the participants' responses toward learning writing skills in the AEC were varied. Two participants (participants $1 \& 3$ ) stated that they were not benefitted from the AEC. On the contrary, the third participant (participant 2) said that he found the AEC very helpful in improving his writing abilities.

The first participant spent four semesters in the AEC and now he was in level four. In his opinion, the levels (1-4) do not concentrate on writing, but instead on listening, speaking and reading. He stated that since his scholarship specified only 24 months for developing the language skills, he was under pressure to obtain the required IELTS score to be admitted to a Master's program. He said that his lower score in writing always dragged down his overall IELTS scores. Therefore, he began with a self-study program to improve his writing skills.

Participant 3 admitted that the AEC did not meet his expectations in writing instruction. The semester, i.e., Fall 2014, was his first semester in the AEC. After the proficiency test he was assigned a level. He stated that the course at this level was only basic. However, he stated that he took the IELTS after he arrived and achieved the required score (6.5/9) to be admitted to a Master's program. He did not clarify the reason why he was assigned low level despite having a high grade in the IELTS test. Also, he stated, like participant 1, that he was relying on self-study to improve his language skills including writing, because the level that he was then was too basic and did not provide him with new information or skills.

Participant 2, who stated that the AEC was beneficial for him as he also joined in the same semester. Following the proficiency test he was assigned with level five, which was the last level in the AEC. Although he said that he considered his speaking skill was weaker than his writing ability, his IELTS scores indicated that his writing was weaker than speaking, as he obtained 6.00 and 7.5 in writing and speaking respectively. Regarding the focus areas of the level, he stated that level five concentrated on writing and it helped him to improve his writing skills. He did not take level four, so we could not compare his experience with participant 1 who stated that levels 1-4 did not provide students with much information about writing.

Regarding the instructors, all participants thought that the instructors in the AEC were much better than those in their English departments in Saudi Arabia in terms of motivation, feedback, and instruction related to teaching of writing skills. Participants 1 and 3 stated that their courses did not concentrate on writing, however, they said that they had learned some basics about writing that they found missing in their Saudi program such as thesis statements and so on. All the participants considered that they were now able to write more effectively in English than when they were studying in Saudi Arabia.

\section{Generalizations \& Observations}

From the experiences of three participants we can see some themes emerging. First, comparing their experiences in learning Arabic writing and English writing in a foreign context shows us some similarities that cannot be ignored. For example, the focus in both cases is on how to organize the content, not on how to develop the content. Also, in Arabic writing classes in school there is no mention of the types of writing. However, English writing has types, such as explanatory, persuasive, and narrative. I was surprised that none of the participants indicated that he had learned one of these types during his four years' study in his BA program in Saudi Arabia.

Another similarity is that different instructors who taught the participants Arabic and English writing in Saudi Arabia did not motivate them to write or encourage them verbally or in writing. Teacher feedback was almost always missing in Arabic writing classes through K-12, as well as in English writing classes in the English department. All of these similarities suggest that teaching strategies for Arabic writing do influence strategies for teaching English writing in the foreign language context.

The participants looked positive at their experiences in learning writing in the AEC with some variations. Although participants 1 and 3 complained that their levels of 4 and 1 respectively did not satisfy their needs in learning writing skills; they thought that overall their experience in the AEC was much better than their experience in their English departments in Saudi Arabia. If we try to distinguish the differences between the two programs it appears that quality of the instructor is the most obvious reason. For instance, participant 1 said that his instructor did not give the students feedback on their assignments. Also, participant 3 stated that he had not been asked to write a complete essay until the final exam and, other than that, their instructor asked them only to write short paragraphs. In contrast to their experience in Saudi, they usually had more practice in the AEC and had more feedback which contributed to improving their writing at different levels.

The AEC program concentrated on writing in the fifth level. However, Saudi students who came to the AEC only had 18-24 months to study language. Therefore, those who started in level one would not have a chance to reach 
fifth level where they would have more instruction in writing. However, the AEC might base its policy on the thought that writing skills cannot be acquired unless other skills are acquired first. This might be true in teaching L1 learners, but teaching adults with more advanced cognitive skills might be different. Two of the participants (1 and 3) complained about how the teaching of writing in the AEC was organized and thought that the AEC should focus on writing from the beginning, not at level five only.

Another noticeable generalization was that the two participants who liked writing in Arabic (participants 2 and 3 ) achieved the required score in IELTS, i.e., 6.5, while though they were new entrants to the AEC. On the other hand, participant 1 who spent two years in the AEC still struggled to achieve that score admitted that he did not like writing in his L1. This raises the question of L1 influence on L2. However, such a small sample prevents us from making this generalization. However this could be treated as a feature for further investigation.

Finally, the data showed that there was a huge difference between teaching writing in foreign and second language contexts in Saudi Arabia and the USA. Unfortunately, there is insufficient research to explore these areas and connect them to writing skills. Although writing is not like speaking and listening, where it is expected that a student can hear and speak more English in a second language context than a foreign language, this study shows that writing is also affected by the contexts as well.

These themes cannot be separated from the contexts that initially emerged. However, more research with more participants should be carried out before generalizing these findings. Furthermore, a one-off interview is not sufficient to explore the participants' experience in one skill, particularly when they are under the pressure of having an admission to a Master's program before the end of a 24-month period.

\section{Conclusion}

This study investigated learners' issues with learning writing skill in English. The learners go abroad to the united states or the UK are the high learners, as the ones who score relatively higher in their cumulative grade points are offered scholarships to study further abroad. It is quite obvious that these learners are high aptitude and serious learners who are completely aware of their requirements and are fully motivated to improve their language skills to further move in their academic achievements. The present study explores the learners chosen from different provinces from the kingdom of Saudi Arabia so as to reach on to a general understanding about the learners' need and the difficulties they face in terms of their writing skill in EFL context. The results shows that the learners need to be motivated in their writing tasks, initially in their own language i.e. their mother tongue as it plays a major role in ESL context as well. The second major observation was that the teaching of English is very much different in Saudi Arabia than the USA. There could be many factors responsible for this as the instructors hired in various universities are from various countries but mostly lacking professional training in ESL teaching. The course content is also not designed properly which would deliver expected outcomes. A firm and more inclusive language policy could be formed which would change the current status of English education in the country. A number of students expressed that they were satisfied with their present writing skills while in fact they still needed to pay tremendous attention to this particular skill. This point needs to be investigated further in order to find out about the students' actual writing ability and identify the problems that they are facing while writing in English. Another key issue that needs to be looked at is students' meta-cognitive awareness of writing strategies and the actual strategies that they implement while writing. To sum up, the present study made a partial contribution to understand students' views and expectations about ESL writing, so that other studies need to be conducted to carefully investigate issues highlighted by the study such as the ones mentioned above.

\section{References}

Ahmed, A. H. (2010). Students problems with cohesion and coherence in EFL essay writing in Egypt: Different perspectives. Literacy Information and Computer Education Journal (LICEJ), 1(4), 211-221. https://doi.org/10.20533/licej.2040.2589.2010.0030

Al-Ali, F. H. (1998). Technical guide for teaching Arabic language (2nd ed.). Amman: Dar Athagafah Bookstpr.

Alharthi, K. M. (2012). The impact of writing strategies on the written product of EFL Saudi male students at King Abdul-Aziz University. $P Q D T-U K \quad \& \quad$ Ireland. Retrieved from http://search.proquest.com/docview/1508805098?accountid=13042\%5Cn

http://oxfordsfx.hosted.exlibrisgroup.com/oxford?url_ver=Z39.88-2004\&rft_val_fmt=info:ofi/fmt:kev:mtx: dissertation\&genre $=$ dissertations $+\&+$ theses $\&$ sid $=$ ProQ:ProQuest + Dissertations $+\&+$ Theses: + U

Al-hazmi, S. H., \& Scholfield, P. (2007). Enforced Revision with Checklist and Peer Feedback in EFL Writing: The Example of Saudi University Students. Scientific Journal of King Faisal University, 8(2), 237-267.

Ali Al-Khairy, M. (2013). Saudi English-major undergraduates' academic writing problems: A Taif university 
perspective. English Language Teaching, 6(6), 1-12. https://doi.org/10.5539/elt.v6n6p1

Aljamhoor, A. (1996). The English writing process of two Saudi graduate students before and after ESL instruction. Michigan State University, USA.

Alnofal, A. I. (2003). Arabic first language writing and English second language writing processes: a comparative study. University of Kansas, USA.

Alrabai, F. (2014). A model of foreign language anxiety in the saudi EFL context. English Language Teaching, 7(7), 82-101. https://doi.org/10.5539/elt.v7n7p82

Alrabai, F. (2016). Factors Underlying Low Achievement of Saudi EFL Learners. International Journal of English Linguistics, 6(3), 21. https://doi.org/10.5539/ijel.v6n3p21

Alshammari, S. (2011). The Attitude of Male and Female Teachers and Students towards Teachers a $\epsilon^{T M}$ Feedback on the Writings of Secondary School Students in Rafha City, Saudi Arabia. Doctoral dissertation, MA Thesis King Saud University, Saudi Arabia.

Alshammari, S. (2016). Improving saudi english learners'second-language acquisition in argumentative writing through self-regulated strategy development. Doctoral dissertation, University of Kansas, USA.

Applebee, A. N., \& Langer, J. A. (2009). EJ Extra: What Is Happening in the Teaching of Writing? Source: The English Journal, 98(5), 18-28. Retrieved from http://www.jstor.org/stable/40503291\%0A http://www.jstor.org/stable/40503291?seq=1\&cid=pdf-reference\#references_tab_contents\%0A http://about.jstor.org/terms

Badger, R., \& White, G. (2000). A process genre approach to teaching writing. ELT Journal, 54(2), 153-160. https://doi.org/10.1093/elt/54.2.153

Bakry, M. S., \& Alsamadani, H. A. (2015). Improving the Persuasive Essay Writing of Students of Arabic as a Foreign Language (AFL): Effects of Self-Regulated Strategy Development. Procedia-Social and Behavioral Sciences, 182, 89-97. https://doi.org/10.1016/j.sbspro.2015.04.742

Barry, D. (2014). The Impact of an English As a Second Language Professional. Clarkston, Michigan.

Biria1, R., \& Yakhabi, M. (2013). Contrastive Rhetorical Analysis of Argumentation Techniques in the Argumentative Essays of English and Persian Writers. Journal of Language, Culture, and Translation (LCT), 2(1), 1-14. Retrieved from file:///Users/Johannes/Documents/研究/研究計畫/103台奧計劃/文獻 /argumentative Perspektivierung/Kontrastive Argumentation.pdf

Britton, J. (1975). The development of writing abilities (pp. 11-18). London: Macmillan.

Connor, U. (1987). Argumentative patterns in students essay: cross cultural differences. In U. Connor \& R. Kaplan (Eds.), Writing across Languages: Analysis of L2 text (pp. 57-71). Reading, Mass: Addsion Wesley.

De La Paz, S., \& Graham, S. (1997). Strategy instruction in planning: Effects on the writing performance and behavior of students with learning difficulties. Exceptional Children, 63(2), 167-181. https://doi.org/10.1177/001440299706300202

Deatline-Buchman, A., \& Jitendra, A. K. (2006). Enhancing Argumentative Essay Writing of Fourth-Grade Students with Learning Disabilities. Learning Disability Quarterly, 29(1), 39-54. https://doi.org/10.2307/30035531

Doushaq, H. H. (1986). An investigation into stylistic errors of Arab students learning english for academic purposes. English for Specific Purposes, 5(1), 27-39. https://doi.org/10.1016/0889-4906(86)90005-0

Elyas, T., \& Picard, M. (2010). Saudi Arabian educational history: impacts on English language teaching. Education, Business and Society: Contemporary Middle Eastern Issues, 3(2), 136-145. https://doi.org/10.1108/17537981011047961

Emig, J. (1971). The Composing Processes of Twelfth Grades. Urbana, IL: National Council of Teachers of English.

Ezza. (2010). Arab EFL Learners' Writing Dilemma at Tertiary Level. English Language Teaching, 3(4), 33-39. https://doi.org/10.5539/elt.v3n4p33

Faigley, L. (1986). Competing Theories of Process: A Critique and a Proposal. National Council of Teachers of English, 48(6), 527-542. https://doi.org/10.2307/376707

Ferretti, R. P., Macarthur, C. A., \& Dowdy, N. S. (2000). The Effects of an Elaborated Goal on the Persuasive 
Writing of Students W, 92(4), 694-702.

Ferris, D. R. (1994). Rhetorical Strategies in Student Persuasive Writing: Differences between Native and Non-Native English Speakers. Research in the Teaching of English, 28(1), 45-65. Retrieved from http://www.jstor.org/stable/40171324

Flower, L., \& Hayes, J. R. (1981). A cognitive process theory of writing. College Composition and Communication, 32(4), 365-387. https://doi.org/10.2307/356600

Graham, S., \& Harris, K. (2013). Designing an effective writing program. In S. Graham, J. MacArthur, \& C. A. Fitzgerald (Eds.), Best practices in writing instruction (pp. 5-25). New York, NY: Guilford Press.

Graham, S., \& Harris, K. R. (1989). Improving learning disabled students' skill at composing essays: Self-instructional strategy training. Exceptional Children, 56, 201-214. https://doi.org/10.1177/001440298905600305

Grami, G. M. A. (2010). The Effects of Integrating Peer Feedback into University-Level ESL Writing Curriculum : A Comparative Study in a Saudi Context. Grami Mohammad Ali Grami Newcastle University, School of Education, Communication and Language Sciences June 2010.

Hashim, N. (1996). English syntactic errors by Arabic speaking learners: reviewed. The Fourth International Symposium on Language and Linguistics, 1441-1465.

Hatim, B. (1990). A Model of Argumentation from Arabic Rhetoric: Insights for a Theory of Text Types. British Society for Middle Eastern Studies, 17(1), 47-54. https://doi.org/10.1080/13530199008705505

Hatim, B. (1997). Communication Across Cultres:Translation Theory and Contrastive Text Linguistics. Exeter: Univesity of Exeter Press.

Hinkel, E. (1997). Indirectness in L1 and L2 academic writing. Journal of Pragmatics, 27, $361-386$. https://doi.org/10.1016/S0378-2166(96)00040-9

Kaplan, R. (1966). Cultural thought patterns in intercultural education. Language Learning, 16(1-2), 1-20. https://doi.org/10.1111/j.1467-1770.1966.tb00804.x

Koch, B. J. (1983). Presentation as Proof: The Language of Arabic Rhetoric. Anthropological Linguistics, 25(1), 47-60. https://doi.org/10.1016/j.jslw.2004.04.003

Liebman, J. D. (1992). Toward a new contrastive rhetoric: Differences between Arabic and Japanese rhetorical instruction. Journal of Second Language Writing, 141-165. https://doi.org/10.1016/1060-3743(92)90013-F

Liu, L. (2005). Rhetorical education through writing instruction across cultures: A comparative analysis of select online instructional materials on argumentative writing. Journal of Second Language Writing, 14(1), 1-18. https://doi.org/10.1016/j.jslw.2004.11.001

M.N., A. A. (2003). Analyzing the generic structures and the rhetorical patterns of the Qur'anic narrative parables. Al-'Arabiyya, 36, 81-106.

Moffett, J. (1968). Teaching the universe of discourse. Boston: Houghton Miffllin Co.

Mohammad, T., \& Hazarika, Z. (2016). Difficulties of Learning EFL in KSA: Writing Skills in Context. International Journal of English Linguistics, 6(3), 105-117. https://doi.org/10.5539/ijel.v6n3p105

Muhammad, H. A. (2001). Arabic composition: Theoretical studies and practical models. Riyadh: Obaikan Bookstore.

Nunan, D. (2000). Seven hypotheses about language teaching and learning. TESOL Matters, 10(2), 1-9.

Nystrand, M. (2006). The social and historical context for writing research. In J. MacArthur, C. Graham, S. Fitxgerald (Ed.), Handbook of Writing Reseach (pp. 11-27).

Parker, R., Lara-alecio, R., \& Gomez, L. (1996). Process versus product writing with limited english proficient students. The Bilingual Research Journal, 209-233. https://doi.org/10.1080/15235882.1996.10668628

Perin, D. (2013). Best practices in teaching writing for college and career readiness. In J. Graham, S. MacArthur, \& C. A. Fitzgerald (Eds.), Best practices in writing instruction (pp. 48-70).

Rababah, G. (2002). Communication problems facing Arab learners of English. Journal of Language and Learning, 3(1), 180-197. Retrieved from http://www.jllonline.co.uk/journal/jllearn/3_1/rababah.pdf 
Raimes, A. (1987). Language Proficiency, Writing Ability, and Composing Strategies- A Study of ESL College Student Writers.pdf. Language Learning, 37(3). https://doi.org/10.1111/j.1467-1770.1987.tb00579.x

Rohman, D. G. (1965). Pre-writing Process in the Writing: The Stage of Discovery. College and Communication, 16(2), 106-112. https://doi.org/10.2307/354885

Rubin, H. J., \& Rubin, I. S. (2011). Qualitative interviewing: The art of hearing data (3rd ed.). Thousand Oaks, Calif. : SAGE.

Seitova, M. (2016). Error Analysis of Written Production: The Case of 6th Grade Students of Kazakhstani School. Procedia-Social and Behavioral Sciences, 232(April), 287-293. https://doi.org/10.1016/j.sbspro.2016.10.022

Sexton, M., Harris, K. R., \& Graham, S. (1998). Self-regulated strategy development and the writing process: Effects on essay writing and attribuitions. Exceptional Children, 64(3), 295-311. https://doi.org/10.1177/001440299806400301

Silva, T. (1988). Comments on Vivian Zamel $\hat{a} €^{\mathrm{TM}} \mathrm{s}$ â $€^{\mathrm{TM}}$ Recent Research on Writing Pedagogy. TESOL Quarterly, 22(3), 517-520. https://doi.org/10.2307/3587296

Silva, T. (1990). Second language composition instruction: Developments, issues and directions in ESL. In B. Kroll (Ed.), Second Language Writing (1st ed., pp. 11-23). Cambridge University Press. https://doi.org/10.1017/CBO9781139524551.005

Silva, T. (1994). An examination of writing program administrators' options for the placement of ESL students in first year writing classes. Writing Program Administration, 18(1-2), 37-44.

Thompson-Panos, K., \& Thomas-Ruzic, M. (1983). The Least You Should Know About Arabic: Implications for the ESL Writing Instructor. TESOL Quarterly, 17(4), 609-623. https://doi.org/10.2307/3586616

Zamel, V. (1976). Teaching Composition in the ESL Classroom: What We Can Learn from Research in the Teaching of English. TESOL Quarterly, 10(1), 67. https://doi.org/10.2307/3585940

Zimmermann, R. (2000). L2 writing: subprocesses, a model of formulating and empirical findings. Learning and Instruction, 10(1), 73-99. https://doi.org/10.1016/S0959-4752(99)00019-5

\section{Copyrights}

Copyright for this article is retained by the author(s), with first publication rights granted to the journal.

This is an open-access article distributed under the terms and conditions of the Creative Commons Attribution license (http://creativecommons.org/licenses/by/4.0/). 